5. Павлов Е.В., Лазарева О.В., Морозова Ю.М. Римское право: Учебное пособие. - Саранск: Издательство ИП Афанасьев Вячеслав Сергеевич, 2020. - 220 с.

6. Петрухин М.В. Проблема определения существенных условий договора участия в долевом строительстве. СПб.: Издательство Университетского издательского консорциума «Юридическая книга» // Российский ежегодник предпринимательского (коммерческого) права. - 2010. - №4. - С. 210 - 223.

7. Подгузова Е.И. История развития договорных оснований прекращения обязательств в римском праве. - М.: Издательство Института деловой карьеры // Общество и право. - 2013. - №2(6). - С. 210 - 213.

8. Постановление Пленума Высшего Арбитражного Суда Российской Федерации от 22 октября 1997 года №18 «О некоторых вопросах, связанных с применением положений Гражданского кодекса Российской Федерации о договоре поставки» // Российская юстиция. - 1998. - №4.

\title{
Славова Н.А. \\ Обеспечение иска в гражданском процессе: сравнительно-правовой анализ законодательства Российской Федерации, Украины, Республики Беларусь
}

Филиал Российского государственного гуманитарного университета

(Россия, Домодедово)

doi: 10.18411/trnio-10-2021-121

\section{Аннотация}

В статье исследуются вопросы обеспечения иска в гражданском судопроизводстве. Проанализированы нормы гражданско-процессуального законодательства Российской Федерации, Украины и республики Беларусь, которые регламентируют процедуру обеспечения иска в гражданском процессе.

Ключевые слова: исковое заявление, суд, гражданское судопроизводство, обеспечение иска, судебная защита, гражданско-процессуальное законодательство, зарубежный опыт.

\section{Abstract}

The article examines the issues of securing a claim in civil proceedings. The article analyzes the norms of the civil procedural legislation of the Russian Federation, Ukraine and the Republic of Belarus, which regulate the procedure for securing a claim in a civil process.

Keywords: statement of claim, court, civil proceedings, securing a claim, judicial protection, procedural legislation, foreign experience.

В соответствии со ст. 46 Конституции Российской Федерации каждому гарантируется судебная защита [1]. Реализация права на судебную защиту зависит от процессуальноправового механизма. Одним из недостатков судебного способа защиты нарушенного права является формальный подход участников судебного процесса к рассматриваемому делу, отсутствие оперативности в принятии процессуальный действий и решений и тд. Особенно печально, когда случаются ситуации, при которых нарушенное право невозможно защитить, поскольку, например, у ответчика прекращено право собственности на имущество, которое было предметом спора. В результате чего, решение суда может остаться без исполнения, и судебная защита прав и интересов истца является неэффективной (сводится к нулю).

В связи с этим, законодатель предоставляет возможность обеспечить иск путем вынесения определения о принятии мер по обеспечению иска.

Институт обеспечения иска гражданского процессуального права состоит из норм, который российский законодатель разместил в требованиях главы 13 «Обеспечение иска» Гражданского процессуального кодекса Российской Федерации (далее - ГПК РФ) [2]. Легальное определение «обеспечение иска» в законодательстве отсутствует, но в то же время законодатель определяет меры по обеспечению иска и процедуру осуществления. Легального определения так же нет и в гражданско-процессуальном законодательстве Республики Беларусь и Украины. 
Значение обеспечения иска заключается в защите законных интересов/прав истца (материально-правовых и нематериально-правовых), в случае невозможности исполнения судебного решения, вследствие определенных действий участников процесса. То есть данная мера должна гарантировать реальное исполнение принятого решения.

Анализ процессуального законодательства Российской Федерации, Республики Беларусь и Украины касательно рассматриваемого вопроса, позволяет сделать вывод, что сроки рассмотрения заявления по принятию мер по обеспечению иска различные. Так, ГПК РФ [2] и Гражданском процессуальном кодексе Республики Беларусь [3] (далее - ГПК РБ) предусмотрено, что заявление об обеспечении иска рассматривается в день его поступления в суд. В Гражданском процессуальном кодексе Украины [4] (далее - ГПК Украины) срок рассмотрения данного заявления - не позднее 2 -х дней с момента поступления в суд. Считаем, что оперативность рассмотрения соответствующего заявления является основным и главным принципом института «обеспечения иска», поскольку без оперативности данный институт процессуального права утрачивает свое правовое содержание. Очевидно, что только оперативность может обеспечить реальное исполнение решения суда и предотвращение возможных злоупотреблений со стороны ответчика.

Важным вопросом также является соразмерность обеспечительных мер к требованиям, которые были заявлены истцом. Российский и украинский законодатель предусмотрел, что меры по обеспечению иска должны быть соразмерны заявленному истцом требованию (п.3 ст. 140 ГПК РФ; п.3 ст. 150 ГПК Украины). В ГПК Белоруссии смысловой текст правовой нормы касательно соразмерности изложен в ином варианте - «суд может допустить одновременно несколько мер обеспечения иска с тем, чтобы общая сумма обеспечения не превышала цены иска» (ст. 225). Не зависимо от того каким образом построен текст правовой нормы законодатель (России, Украины, Республики Беларусь) не дает чёткого определения тому, где заканчиваются и начинаются границы обеспечительных мер.

Данные нормы содержат оценочные суждения, что является недопустимым для регламентации настолько объемных правоотношений. Правильно сделал вывод Сухаруков А.Ю., что необходимо сформулировать несколько предписаний, которые позволят более четко регулировать процедуру осуществления обеспечительных мер. К таковым следует относить следующие: 1) суду необходимо оценивать, обосновано ли заявление истца об обеспечении иска, соответствует ли заявление предмету спора или нет; 2) следует предусмотреть, какие потери может понести заявитель в том случае, если суд откажет в обеспечении иска; 3) при осуществлении обеспечительных мер важно соблюдать баланс интересов участников процесса; 4) если суд примет решение об обеспечении иска, он должен помнить о недопущении нарушения публичных интересов третьих лиц [5, с. 237].

Конечно, соразмерные обеспечительные меры требованиям, заявленным истцом, необоснованно не ущемляющие права ответчика, являются важной гарантией защиты и существенного восстановления прав и требований участников гражданского процесса не только в обеспечении иска, но и в иных процессуальных действиях. Однако вопрос соразмерности выбора обеспечительных мер является весьма дискуссионным, поскольку законодатель не раскрывает определения адекватной и соразмерной обеспечительной меры, в результате данные термины носят весьма субъективный характер. В связи с этим, требуется тщательная оценка объективной необходимости обеспечительной меры, в том числе соблюдения принципа её соразмерности заявленным требованиям, что является важнейшей задачей гражданского судопроизводства [6, с. 58].

Виды мер по обеспечению иска в Российской Федерации, Украине, Республики Беларусь, в большей степени, являются идентичными (наложение ареста на имущество, запрещение совершать определенные действия и тд.), однако имеются и различия. Например, В Украине к видам обеспечения иска относят - совершение определенных действий, если спор возник из семейных правоотношений; приостановление таможенного оформления товаров; арест морского судна. В Российской Федерации отдельным видом обеспечение иска 
является - совершение определенных действий, касающиеся предмета спора о нарушении авторских и (или) смежных прав; в Республике Беларусь - временное ограничение права ответчика на выезд из страны.

Стоит обратить внимание, что в отличии от процессуального законодательства Белоруссии, в ГПК Украины и ГПК РФ предусмотрены не только запрет (запрещение) в совершение каких-либо действий, но и возложение на лица обязанности совершить определенные действия. Считаем, что такие меры по обеспечению иска являются оправданными, тем более что в ряде случаев одним из наиболее эффективных способов защиты гражданских прав, является необходимость совершения ответчиком определенных действий, влекущих устранение допущенного нарушения (ст. 206 ГПК РФ).

Так же стоит отметить, что обеспечение иска путем запрета совершать определенные действия или запрета другим лицам осуществлять определенные действия, например, передавать имущество или выполнять иные обязательства заключается в том, что путь быстрого и надежного сообщения обязанных лиц о наличии таких запретов в ГПК (РФ, Украины, Республики Беларусь) не установлен. Более того, когда же лицо настаивает, что не получало таких сообщений, и не существует доказательств такого предупреждения, то привлекать ее к ответственности считаем невозможным.

Кроме того, в данных процессуальных действиях часто возникает вопрос: как должен действовать суд в случае поступления заявления об обеспечении иска вместе с исковым заявлением (такие случаи являются довольно распространенными на практике)? Может ли суд обеспечить иск до возбуждения гражданского дела в суде? Как действовать суду, когда при проверке искового заявления, которое было направлено вместе с заявлением об обеспечении иска, будут выявлены основания для возвращения искового заявления или оставления без движения?

На наш взгляд, более детально к этому вопросу подошел украинский законодатель, где ст. 152 ГПК Украины посвящена порядку подачи заявления об обеспечении иска. Так, в данной норме определено, что заявление об обеспечении иска подается: 1) до подачи искового заявления; 2) одновременно с исковым заявление; 3 ) после открытия производства по делу. Кроме того, статьей 151 ГПК Украины определена форма и содержание такого заявления.

Считаем, что порядок подачи заявления об обеспечении иска, а также его форма и содержание должны быть детально регламентированы процессуальным законодательством.

Таким образом, в условиях продолжающихся процессов реформирования гражданскопроцессуального законодательства, необходимо анализировать международный опыт, который поможет определить алгоритм современного формирования и становления правового института обеспечение иска в гражданском процессе. Анализ зарубежного опыта, проведенного, показывает, что определенные направления в исследуемой тематике можно, было бы реализовать и в нашей практики.

$$
* * *
$$

1. Конституция Российской Федерации (принята всенародным голосованием 12.12.1993 г. с изменениями, одобренными в ходе общероссийского голосования 01.07.2020) [Электронный ресурс]. - Режим доступа: http://www.consultant.ru/document/cons_doc_LAW_28399/

2. Гражданский процессуальный кодекс Российской Федерации от 14 ноября 2002 г. N 138-Ф3 (ред. от 01.07.2021) [Электронный pecypc]. http://www.consultant.ru/document/cons_doc_LAW_39570/

3. Гражданский процессуальный кодекс Республики Беларусь от 11 января 1999 г. № 238-3 (ред. от 14.05.2021) [Электронный ресурс]. - Режим доступа: https://pravo.by/document/?guid=3871\&p0=hk9900238

4. Гражданский процессуальный кодекс Украины от 18 марта 2004 г.№ 1618-IV (ред. от 30.06.2021) [Электронный ресурс]. - Режим доступа: https://zakon.rada.gov.ua/go/1618-15

5. Сухаруков А.Ю. Актуальные проблемы обеспечения иска в гражданском процессе // Научный журнал «Эпомен». - 2021 - № 51. - С. 237-242.

6. Комлев Н.Ю., Бякин Я.С. Актуальные вопросы обеспечения иска в гражданском процессе // Казанский юридический институт МВД России. - 2021 - № 1. - С. 55-59. 